\title{
Human Rights and the Clean Development Mechanism
}

This is an Accepted Manuscript of an article published by Taylor \& Francis Group in Cambridge Review of International Affairs (vol. 27, no. 4, 2014, pp. 717-735), available online:

http://www.tandfonline.com/10.1080/09557571.2014.961407

DOI: $10.1080 / 09557571.2014 .961407$ 
Jeanette Schade ${ }^{a,{ }^{*}} \&$ Wolfgang Obergassel ${ }^{b}$

\title{
Human Rights and the
}

Clean Development Mechanism

\author{
a Bielefeld University, Bielefeld, Germany \\ b Wuppertal Institute für Climate, Environment and Energy, Wuppertal, Germany
}

* Corresponding author: Jeanette Schade, Bielefeld University, Faculty of Sociology, PO Box 100131, 33501 Bielefeld, Germany

E-mail: jeanette.schade@uni-bielefeld.de

Phone: +49 5211064635 


\title{
Human Rights and the Clean Development Mechanism
}

\begin{abstract}
The 2010 UN climate conference in Cancún emphasised that 'Parties should, in all climate change related actions, fully respect human rights'. However, so far there is no further guidance. This article discusses the relevant legal human rights norms and two case studies from the Kyoto Protocol's Clean Development Mechanism (CDM). The first case (Bajo Aguán, Honduras) shows that the current absence of any international safeguards can lead to registration of highly problematic projects. The second case (Olkaria, Kenya) suggests that safeguards, introduced here as a side effect of World Bank involvement, can have a positive impact, but that it is necessary to have them based on human rights. It therefore seems recommendable for the UN climate regime to develop mandatory human rights safeguards. In addition or alternatively, individual buyer countries or groups of countries, such as the EU, could introduce their own additional requirements for CDM projects.
\end{abstract}




\section{Introduction}

Climate change mitigation requires the fundamental restructuring of economies. This shift entails large-scale investments in the near future, which - as all large-scale projects - have a high potential to infringe human rights. In 2009, a report of the Office of the UN High Commissioner for Human Rights (OHCHR) highlighted 'human rights implications' of climate change response measures and states' respective human rights duties. ${ }^{1}$ The United Nations Framework Convention on Climate Change (UNFCCC) is based on the principle of sustainable development, whose links to human rights have been made explicit in the nonbinding 1992 Rio Declaration on Environment and Development and its follow-ups. ${ }^{2}$ However, the UNFCCC and its mechanisms perpetuate an understanding of sustainability which is reduced to abating greenhouse gas emissions. It was only in 2010 at the $16^{\text {th }}$ Conference of the Parties to the UNFCCC (COP 16) that governments acknowledged 'that Parties should, in all climate change related actions, fully respect human rights'. ${ }^{3}$ While COP decisions are non-binding, human rights are laid down in legally binding international treaties. The COP 16 text is therefore an acknowledgement that the international climate regime needs to be designed in coherence with the human rights regime.

This article analyses the Kyoto Protocol's Clean Development Mechanism (CDM) from a human rights perspective. The CDM was chosen because it is so far the largest international mitigation policy instrument for developing countries. It has about 7,500 registered projects, with another 1,400 projects in the pipeline (UNEP Risø 2014). At the same time, due to greater socio-economic and socio-political inequalities as well as weak human rights institutions, the infringement of human rights is more likely in developing than in industrialised countries.

The article first outlines relevant human rights norms which are, by experience, frequently impaired by large-scale projects and discusses the responsibility of external actors. Next, the article looks into the characteristics of the CDM and the pitfalls experienced in aligning it with human rights standards. The article then discusses two CDM projects, the case of Bajo Aguán in Honduras and the case of Olkaria in Kenya. The two cases were chosen to contrast different situations regarding the application of international safeguards in projects. The Bajo Aguán project is a purely private investment and does not involve international finance or development cooperation. As the CDM approval process does not

\footnotetext{
A/HRC/10/61 of 15 January 2009, Art. 65-68.

2 See A/CONF.151/26 (Vol. I) of 12 August 1992, principle 3 and para. 7.6; A/CONF.151/26 (Vol. II) of 13 August 1992, para. 18.42; A/CONF.151/26 (Vol. III) of 14 August 1992, para. 5; and A/RES/66/288 of 11 September 2012, paras. 9, 58(d), 108, 121, 138, 145, 157, and 229. While these are non-binding, the human rights norms they refer to are laid down in legally binding treaties.
}

3 Decision 1/CP.16, FCCC/CP/2010/7/Add.1 of 15 March 2011, para 8. 
include any social standards this project is thus characterised by the complete absence of international safeguards. In contrast, the Olkaria project is co-financed by international lenders, including the World Bank and the European Investment Bank (EIB), which makes the project subject to the World Bank's operational policies.

The case analysis was conducted as desk studies based on publicly available material. The selected cases serve to conceptualise the role of human rights in the CDM in order to lay the basis for further empirical research, which has so far been lacking. While there is a substantial amount of peer reviewed literature on technical design problems and the environmental effectiveness of the CDM, there has so far been only little empirical work on negative social and human rights impacts of CDM projects (TERI, 2012).

\section{Development, Climate Policies, and Human Rights}

Large-scale development investments always come at a cost, which is often borne by the weakest segments of society. For example, during the 1990s alone between 90 and 100 million people were evicted globally due to infrastructure programmes (dams, urbanization, roads, etc.) (Cernea 1997, 1570). Climate policies today need to take into account the experiences from large-scale projects of the past to avoid making the same mistakes. Depending on the severity of livelihood infringements, large-scale investments in green development pathways potentially threaten the enjoyment of human rights (Schade 2012).

Human rights law is usually interpreted as defining vertical duties of the state towards individuals and certain groups under its jurisdiction. Generally, states have a threefold duty: the negative duty to respect (not to breach human rights), and the positive duties to protect (from human rights breaches by third parties) and to fulfil (using active measures to realize) human rights. With respect to the CDM this means that host countries bear the primary responsibility when projects negatively impact human rights. However, due to the substantial involvement of external actors in the CDM, such as project developers, donors, international financial institutions, and buyers of carbon credits, the question of extra-territorial obligations (ETOs) of states arises, i.e. which duties states have towards individuals and groups who are outside of their jurisdiction. Equally the responsibilities of the involved business entities to respect human rights have to be discussed. Before doing so the following outlines the relevant human rights norms. 


\subsection{Relevant Norms}

The UN Human Rights Charter, consisting of the Universal Declaration of Human Rights (UDHR) and the two major international human rights treaties, the International Covenant on Civil and Political Rights (ICCPR) and the International Covenant on Economic, Social and Cultural Rights (ICESCR), provide for a series of substantive and procedural rights. Regional human rights treaties are of similar content.

The ICCPR protects the right to life (Art. 2(1)) and the right to liberty and personal security as well as the right to physical, psychic and moral integrity (Art. 7). Both might be of relevance in situations where investments contribute to violent conflicts. The right to life, moreover, is frequently used in human rights jurisdiction to condemn life-threatening changes in the environment (Knox 2009, 13). Additionally, the ICESCR provides for the right to an adequate standard of living, 'including adequate food, clothing and housing, and to the continuous improvement of living conditions' (Art. 11), and for the right to health (Art. 12). From these two articles the ICESCR treaty body derives the right to water because water is 'fundamental for life and health'. 4

Crucial in the context of development-based evictions is the right to property, which protects from expropriation or at least from expropriation without adequate compensation. The right to property is laid down in the UDHR Art. 17 and in all regional civil and political human rights treaties. ${ }^{5}$ Of particular relevance is the question of land ownership, which often leads to violent conflicts in the context of large-scale investments. ${ }^{6}$ The right to housing addresses this problem by defining 'legal security of tenure' to be part of it. ${ }^{7}$ The question of land and land ownership is of particular concern where mitigation projects expand into the territories of indigenous people, as it is frequently the case, for example, with forest programmes or hydropower stations. The binding Convention 169 of the International Labour Organisation on Indigenous and Tribal Peoples in Independent Countries (ILO Convention $169)$ explicitly recognises the collective property of natural resources of indigenous peoples. ${ }^{8}$ Human rights treaty bodies have also frequently supported the rights of indigenous peoples to their ancestral lands, based on ICCPR Art. 27 on minority rights (MacKay 2002, 595ff.). ${ }^{9}$

\footnotetext{
4 E/C.12/2002/11 of 20 January 2003, para.1.

5 European Convention, Protocol 1, Art. 1; American Convention, Art. 21; OAS Declaration, Art. 23; African Charter, Art. 14 and Art. 21. The right to property is not included in the two international covenants.

6 E/C.12/1997/4 of May 1997, para. 7.

7 E/1992/23 of 13 December 1991, para. 8.

8 ILO Convention 169 on Indigenous and Tribal Peoples in Independent Countries, Art. 14(1).

9 For an overview on landmark cases of regional treaty bodies see Knox (2009), MacKay (2002, 589-606) and Ward (2011, 61-63). For the African context additionally Centre for Minority Rights Development and Minority Rights Group (on behalf of Endorois Welfare Council) v. Kenya, 2009 ACHPR, No. 276/03, 46th Ordinary
} 
Procedural norms are equally of high relevance. The Inter-American Commission on Human Rights regards access to information, participation in decision-making processes, and access to legal remedies as crucial measures to support and enhance the ability of individuals to safeguard and vindicate [their] rights'. ${ }^{10}$ Similar judgements have been produced by other treaty bodies (Knox 2009, 198ff.).

Again, due to their way of life indigenous peoples are often particularly vulnerable to breaches of such procedural requirements. To protect them from potentially existencethreatening investment activities, the Inter-American Court of Human Rights (IACtHR) occasionally extended the duty to consult to a duty to obtain free, prior, and informed consent (FPIC). ${ }^{11}$ The meaning of 'consent' is, however, disputed, in particular whether it contains a right to veto projects. At a minimum it means that indigenous people have to be consulted in 'good faith' with the 'objective of consent' and prior to project start, as also enshrined in ILO Convention 169, Art. 6(2). The most extensive interpretation of FPIC (as well as of indigenous peoples' property rights) is provided by the non-binding UN Declaration on the Rights of Indigenous Peoples (UNDRIP). UNDRIP was supported by more than 140 states and some treaty bodies refer to UNDRIP as an international standard (Ward 2011, 58f, 66).

\subsection{Extraterritorial Obligations and Obligations of Business Actors}

The question remains whether it is only the host state of a CDM project which bears the duties to respect, protect and fulfil the human rights of the local population. Traditionally, ETOs have been interpreted as being limited to undertaking steps 'individually and through international assistance and co-operation ... with the view to achieving progressively the full realization of the rights recognized by the [ICESCR] ...', which includes the adoption of political and legislative measures. ${ }^{12}$ However, for about a decade a broader interpretation of ETOs has been promoted by human rights treaty bodies and progressive legal experts.

Contemplating the legal meaning of ICESCR Art. 2(1), scholars deduct an extraterritorial duty of states to respect by requiring 'to ensure that [a state] does not undermine the enjoyment of rights of those in foreign territory' (Craven 2007, 253) and not to 'interfere with other states' ability to meet their obligations' (Knox 2009, 206). General Comment 15 of the CESCR laid down that interference comprises direct actions as well as

\footnotetext{
Session, 11-25 November 2009.

10 OEA/Ser.L/V/II.96 doc. 10 rev. 1 of 24 April 1997,, 91, fn34.

11 Saramaka People v. Suriname; IACtHR 2007 (Ser. C) No. 172.

${ }^{12}$ ICESCR, Art 2(1)
} 
policies that (foreseeably) negatively affect the right to water. ${ }^{13}$ In General Comment 14 on the right to health, the CESCR derives an additional extraterritorial duty to protect people outside the own territory from human rights violations by third parties, 'if they are able to influence these third parties by way of legal or political means .....14 The Maastricht Principles provide the most comprehensive and progressive interpretation of existing legal texts with regard to ETOs. They emphasise, for example, states' obligations to conduct impact assessments and prevention measures, and to elaborate, to interpret and apply international agreements in accordance with human rights obligations (International Commission of Jurists, ICJ 2011).

With respect to international organisations, the commentary on the Maastricht Principles details that a state, as a member of such organisations, has to use its decisionmaking power to ensure that an organisation 'acts in accordance with the pre-existing human rights obligations of the State' (Schutter et al. 2012). ${ }^{15}$ International organisations are, moreover, per se subjects of international law and thus have to respect international customary law and its general principles such as non-discrimination. Specialised UN agencies such as the World Bank are additionally bound to the provisions of the UN Charter (MacKay 2002, 580f.). A special case for ETOs is, finally, the European Union (EU). The Treaty of the European Union, amended by the Lisbon Treaty of 2009, enshrines the EU's commitment to human rights in its external relations with the 'wider world' in Articles 2, 3(5), and 21 (Bartels 2014, 15).

Finally, the Guiding Principles on Business and Human Rights endorsed by the Human Rights Council in June 2011 ('Ruggie Guidelines') specifically address the question of protecting from violations by 'third parties' as well as the duties of business actors themselves. Though the guidelines question a generally legally binding duty of states 'to regulate the extraterritorial activities of businesses domiciled in their territory and/or jurisdiction', they see 'strong policy reasons' to do so. ${ }^{16}$ In situations with a state-business nexus they call on states to require human rights due diligence from companies, even beyond their territorial borders (Heydenreich et al. 2014, 32). ${ }^{17}$ Due diligence is required in all business relationships, along the entire value chain. ${ }^{18}$

\footnotetext{
${ }^{13}$ E/C.12/2002/11 of 20 January 2003, paras. 31-36.

14 E/C.12/2000/4 of 11 August 2000, para. 39.

15 See also the Ruggie Guidelines: A/HRC/17/31 of 21 March 2011, para. 10, commentary.

16 Ibid. para. 2, commentary.

17 Ibid., paras. 4-9.

${ }^{18}$ Ibid. para. 13, commentary.
} 
According to the Ruggie Guidelines corporate responsibilities to respect human rights include appropriate measures to prevent, mitigate, and remedy human rights infringements and abuses. ${ }^{19}$ The guidelines also recommend the consideration of internationally agreed instruments that elaborate inter alia on the rights of 'specific groups', including the 'rights of indigenous peoples' and 'ethnic minorities' ${ }^{20}$ In addition to available state-based complaints mechanisms the guidelines moreover recommend in paragraphs $31(d)$ and $(h)$ to establish operational-level grievance mechanisms that address imbalances between stakeholders and which provide for a legitimate and independent third-party mechanism if adjudication is needed.

In sum, there exist several extraterritorial human rights duties in the context of the CDM. States which are parties to human rights treaties and to the UNFCCC have an obligation to use their negotiation and voting power to work towards ensuring that the UNFCCC and its mechanisms do not jeopardise human rights. Similarly, the World Bank and other lending institutions and their board members have a responsibility to ensure that the projects they support do not harm human rights. And finally, there even exist international agreed guidelines how investing business actors, domestic and international ones, should respect human rights and be regulated accordingly.

\section{The Clean Development Mechanism and Human Rights}

The CDM as an international mechanism to stimulate climate-friendly investments can be regarded to have a strong state business-nexus. In particular the project registration procedure offers ample means to influence business behaviour.

The CDM is based on Article 12 of the Kyoto Protocol. Article 12.2 sets out two equally weighted objectives: to assist developing countries in achieving sustainable development and to assist industrialised countries in achieving compliance with their emission reduction commitments. Once a CDM project has completed a pre-determined project cycle, the project participants receive emission reduction credits, so-called Certified Emission Reductions (CERs), which industrialised countries can purchase and count towards their Kyoto commitments. Industrialised country governments may be directly involved in projects, but the usual model is the purchase of CERs from projects operated by private businesses. Some jurisdictions such as the EU have also established domestic emission trading systems (ETS) where companies may use CERs to comply with domestic obligations.

\footnotetext{
${ }^{19}$ Ibid., para. 11, commentary.

${ }^{20}$ Ibid., para. 12, commentary.
} 
The CDM 'modalities and procedures', adopted as part of the Marrakesh Accords $(M A)^{21}$ in 2001 , set out the detailed rules for the implementation of projects. ${ }^{22}$ Governance of the CDM lies with the CDM Executive Board ('Board'). Project proponents need to prepare a Project Design Document (PDD) according to a prescribed format developed by the Board. The PDD needs to be validated, i.e. examined as to whether it meets all CDM requirements, by an independent certification company accredited with the Board, called Designated Operational Entity (DOE). The project needs to be approved by the countries involved, that is, the host country and the buyer country or countries. If all requirements are met, the project is formally registered by the Board and may subsequently be issued CERs, subject to adequate monitoring of the achieved reductions by the project participants and verification by another DOE.

The CDM modalities and procedures deal almost exclusively with questions of how to quantify emission reductions. There is no mention of human rights. The only hook for human rights concerns is the requirement that projects contribute to sustainable development and a requirement to invite and duly take account of stakeholder comments. All these items are addressed as part of the PDD.

However, there are no internationally agreed criteria or procedures for assessing CDM projects' contributions to sustainable development, nor are there internationally agreed procedures for conducting local stakeholder consultations. While the EU suggested including such standards and procedures when the MA were negotiated, developing countries rejected these proposals as being incompatible with their national sovereignty (Yamin and Depledge 2004). The MA therefore do not go beyond requiring confirmation by the host country that the project assists it in achieving sustainable development, without giving further specification. ${ }^{23}$

The stakeholder consultation has two levels, local stakeholder consultation and global stakeholder consultation. Regarding local stakeholder consultations, the MA merely state that comments shall be invited and that the project participants need to provide a summary of the comments received and a report of how any comments received were duly taken into account. ${ }^{24}$ There is no specification of who exactly to consult and how to consult them. Rules for the global stakeholder consultation are somewhat more specified. The DOE needs to make the PDD publicly available for 30 days for comments from Parties, stakeholders and

\footnotetext{
21 The Marrakesh Accords contain detailed implementation rules for the Kyoto Protocol, particularly regarding emissions accounting and the functioning of (the) flexible mechanisms.

22 Decision 3/CMP.1, FCCC/KP/CMP/2005/8/Add.1 of 30 March 2006.

${ }^{23}$ ibid., para. 40a.

24 ibid., para. $37 \mathrm{~b}$.
} 
UNFCCC accredited non-governmental organizations and needs to make the comments received publicly available as well. ${ }^{25}$

It is therefore up to host countries to define sustainable development criteria and procedures for local stakeholder consultations. Research (e.g. Olsen 2007; Schneider 2007; Sterk et al. 2009) has concluded that most host countries have rather general lists of nonbinding guidelines instead of clear criteria. This makes it easy to comply with requirements: PDD sections on sustainable development as well as validation reports tend to have vague wording avoiding concrete and verifiable statements. Similarly, stakeholder consultation is often rudimentary, unregulated and badly documented. Most host countries do not thoroughly investigate projects. Furthermore, all these processes take place before project implementation. The CDM rules contain no mechanisms for addressing problems that may not have been visible in the project design and approval phase.

Due to public criticism, there have recently been new discussions on how to strengthen sustainable development assessments and stakeholder consultations. Based on a mandate from the Kyoto parties, the UNFCCC Secretariat in early 2012 developed a comprehensive draft for a voluntary tool to assess sustainable development impacts, including a human rights-based 'do no harm' assessment, and also suggested to adopt detailed requirements for stakeholder consultations. However, as in Marrakesh, most developing country representatives on the Board rejected these suggestions as incompatible with host countries' sovereignty. The Board therefore mandated the Secretariat to develop a much-reduced draft on stakeholder consultations and substantially cut down the sustainable development tool. The remaining parts of the tool allow indicating only positive but not negative impacts (Sterk 2012).

The 2013 climate conference in Warsaw requested the Board to work with national CDM authorities on collecting and making publicly available information on existing practices for local stakeholder consultations, and to provide technical assistance for developing stakeholder consultation guidelines to national authorities, upon their request. ${ }^{26}$

\footnotetext{
25 ibid., para. 40c.

${ }^{26}$ Decision 3/CMP.9, FCCC/KP/CMP/2013/9/Add.1 of 31 January 2014, para. 20.
} 


\section{Cases}

\subsection{The Bajo Aguán Case in Honduras}

The CDM project has the official title 'Aguan biogas recovery from Palm Oil Mill Effluent (POME) ponds and biogas utilisation - Exportadora del Atlántico, Aguan/Honduras'. According to the PDD, the project optimises the wastewater treatment system of the palm oil mill, which hitherto consisted of open lagoons emitting biogas into the atmosphere. The feasibility study for the installation was finalised in November 2006 and the project started on 23 July 2007 (Exportadora del Atlántico 2011).

Exportadora del Atlántico is a subsidiary of Grupo Dinant, owned by the family of Miguel Facusse (CDM Watch 2011a). Originally, the project also involved the Londonbased EDF Trading Limited as further project participant and prospective buyer of the credits, and the United Kingdom of Great Britain and Northern Ireland as home country of EDF Trading (Exportadora del Atlántico and EDF Trading 2007).

The palm oil supplied to the mill comes from plantations that are at the centre of a violent land dispute. Since 2004, local peasant organisations have claimed that Facussé appropriated the lands of the plantations illegally from small-scale farmers. An agreement to establish a legal commission was reached in 2009 and signed by then President Zelaya. However, its implementation was pre-empted by a coup d'état that took place on 28 June 2009. There have since been numerous armed confrontations between farmers and public and private security forces (FIDH et al 2011; Frank 2011).

Honduras is party to the ICESCR, to the ICCPR, and to the American Convention on Human Rights. ${ }^{27}$ Honduras also ratified ILO Convention $169^{28}$ and supported the UNDRIP as well as the Rio Declaration and subsequent declarations on sustainable development. ${ }^{29}$ The government of Honduras has nonetheless reportedly violated the peasants' human rights in many instances.

By now, more than 50 peasants and supporters have reportedly been killed in the land conflict by public and private security forces (FIAN International 2013). The state of Honduras is thus failing its obligations to respect and protect the right to life. In addition, according to FIDH et al (2011), Honduras is also failing its obligations to respect and protect

\footnotetext{
27 See United Nations Treaty Collection, http://treaties.un.org.

28 Ratifications of C169 - Indigenous and Tribal Peoples Convention, 1989 (No. 169), http://www.ilo.org/dyn/normlex/en/f?p=1000:11300:0::NO:11300:P11300_INSTRUMENT_ID:312314, accessed 17 January 2013.

${ }^{29}$ See United Nations Bibliographic Information System, Voting Records, http://unbisnet.un.org/\#voterecords.
} 
the peasants' right to liberty and personal security as well as the right to physical, psychic and moral integrity as the peasants are reportedly being subjected to constant threats, harassment in public and at home through telephone calls and surveillance, burning of houses, armed attacks, illegal arrests, kidnappings, torture and sexual abuses. In May 2010, the Inter-American Commission on Human Rights (IACHR) visited Honduras and, among other things, expressed their concerns, particularly about Executive Decree PCM-014-2010, which instructs the Secretariat of National Defense to provide Armed Forces personnel and equipment to aid the National Police. ${ }^{30}$ The IACHR again expressed deep concerns on the situation in Bajo Aguán at the close of its 143rd regular session in 2011 (IACHR 2011).

Regarding procedural rights, IACHR and the OHCHR have determined that, since the coup d'état, public and private security forces have committed numerous human rights violations in Honduras, including the Bajo Aguán region, with impunity, and that victims have no legal recourse. ${ }^{31}$ As late as February 2013 , four years after the coup, the OHCHR stated after a visit to Honduras that human rights violations 'are not investigated, perpetrators remain unprosecuted and victims do not have access to remedies' (OHCHR 2013).

It is not clear whether the mill and thus the CDM project itself is directly causing or contributing to the alleged human rights violations (TERI 2012). The available material does not explicitly refer to the CDM project as directly causing violations, but CDM Watch (2011a) alleges that the palm oil mill is sourcing its raw material from the plantations that are the object of the land dispute. In addition, the affected population and non-governmental organisations have accused security guards working for the project owner Facussé as being among the primary perpetrators of the alleged human rights violations, acting in concert with public security forces (CDM Watch 2011a, FIDH et al 2011). According to Frank (2011), Facussé himself admitted that guards working for him killed five peasants on 15 November 2010

Nonetheless, the CDM process did not take these considerations into account even though it mostly took place after the start of the violence. According to the validation report, the final version of the PDD dates from 25 January 2011. The validation report itself dates from 31 January 2011. It nonetheless makes no mention of the violent conflict that had surrounded the project and its owner since 2004 and the associated violence that had taken place since 2009 .

\footnotetext{
${ }^{30}$ OEA/Ser.L/V/II. of 3 June 2010, The IACHR again expressed deep concerns regarding the situation in Bajo Aguán at the close of its 143rd regular session (IACHR Media Center 2011).

31 A/HRC/13/66 of 3 March 2010; OEA/Ser.L/V/II. of 30 December 2009; OEA/Ser.L/V/II. of 3 June 2010.
} 
To what extent the local population was consulted is also unclear. According to the PDD, stakeholder consultations had taken place in $2007 / 2008$, that is, at a time when the land conflict was already ongoing but before the escalation after the coup d'état. The validation report by the DOE TÜV Süd states that 'the local stakeholder consultation has been adequately performed according to the CDM requirements' (TÜV Süd 2011, 24f.). However, the adequacy of the consultation cannot be verified externally since key documentation is not publicly available. The CDM PDD and the validation report neither include copies of the newspaper advertisements that were supposedly published, nor do they contain lists of the invitees and attendants of the stakeholder meeting that was supposedly carried out. The validation report also does not specify what steps were taken by the validators to assess the validity of the information and the adequacy of the consultation.

NGOs raised the human rights issues with the CDM Executive Board (CDM Watch 2011a; 2011c), but the Board nevertheless decided to register the project in July 2011. While the Board did not react officially to the human rights allegations, its then chair, Martin Hession, told the news website EurActiv that they had no means to block registration since their mandate covered only the GHG impacts of projects (EurActiv 2011).

After the UK government, which had issued a letter of approval to the project, had been made aware of the allegations by CDM Watch (2011b), then UK Energy and Climate Secretary Chris Huhne responded that the allegations were 'disturbing' but pointed to the host country as having primary responsibility regarding sustainable development (Huhne 2011). Finally, so far no CERs have been issued to the project, but when they are, there is no mechanism to stop these credits from being imported into the EU and used in the EU ETS.

In conclusion, the CDM modalities and procedures leave the question of whether a project contributes to sustainable development at the discretion of the host country. This leaves no remedy for cases where the host country government itself is involved in human rights violations, as is allegedly the case in Bajo Aguán. While it is not clear whether the palm oil mill and thus the CDM project itself is causing additional human rights violations, the mill reportedly sources its raw material from land that has been the object of violent conflicts for almost a decade. The local population and non-governmental organisations have accused the owner of the CDM project, Miguel Facussé, as being among the persons that are most responsible for the alleged human rights violations. The mill does thus not comply with due diligence standards set out by the Ruggie Guidelines. Nonetheless, the CDM Executive Board and the UK government did not take the human rights issues into account when deciding on the CDM project. The Board and the UK government thus arguably failed to comply with their responsibility to design and govern new institutions according to their pre- 
existing human rights obligations. By enabling additional revenue for Facussé's mill, state parties to the UNFCCC run the risk that this may 'entail a violation of the states' own international law obligations. ${ }^{32}$ While refusal to register the project under the CDM might not have made a difference for the human rights situation, it would have prevented the provision of international resources to an alleged perpetrator of grave human rights violations.

\subsection{The Olkaria Case in Kenya}

Kenya is party to the ICCPR and to the ICESCR as well as to the Convention Against Racial Discrimination. ${ }^{33}$ Moreover, it supported the Rio Declaration and subsequent declarations on sustainable development.

Kenya has four geothermal power projects located in the Olkaria area registered as CDM projects (UNEP Risø 2014). Except for Olkaria III, all Olkaria power plants are operated by the parastatal Kenya Electricity Generating Company (KenGen). The plant expansions take place under the Kenyan Electricity Expansion Program (KEEP) of the World Bank, which aims to improve electricity supply within the country. As the African Commission on Human and Peoples Rights (ACHPR) advised the World Bank to address UNDRIP in its cooperation with African governments (Republic of Kenya 2010, 8f.), Kenya was requested to submit an Indigenous People Planning Framework (IPPF) for KEEP, which requires the application of the Bank's operation policy OP 4.10 on indigenous peoples (World Bank 2005). However, the consent principle of FPIC is officially objected to by the World Bank, which particularly rejects a right to veto resettlements if such measure are deemed necessary to implement a (co-)funded project (World Bank 2004; Tamang 2005, 11). Thus the ' $C$ ' is limited to consultations.

The Olkaria area is home to various clans of the pastoralist Maasai. The Maasai are recognised as an indigenous people by the African Commission's Working Group on Indigenous People (ACHPR-WG 2006, 10). The Maasai of Olkaria have been victims of dubious land deals and development-related forced evictions for more than a century (TJRC 2013a, 9; TJRC 2013b, 297f.; CEMIRIDE n.d.). The case study focuses on Olkaria IV and the related resettlement process, which takes place in the context of ongoing land disputes between the Maasai and the official proprietors.

\footnotetext{
${ }^{32} \mathrm{~A} / \mathrm{HRC} / 17 / 31$ of 21 March 2011, para. 4, commentary.

33 See United Nations Treaty Collection, http://treaties.un.org.
} 
Olkaria IV and the resettlement scheme is substantially co-funded by the European Investment Bank (EIB), the French Development Agency (ADF), the German Kreditanstalt für Wiederaufbau (KfW) and the World Bank. The crucial social safeguard applied by the project is the World Bank's operational policy OP 4.12 on involuntary resettlement (World Bank 2001). Three villages have to be resettled from Kedong Ranch to give way to the new plant, and additionally one village on Maiella Ranch has to be vacated due to projected air pollution. In line with OP 4.12 and national policies, KenGen and GIBB Africa, a consultant firm, developed a resettlement action plan. According to this plan all four villages are to be resettled into one new village, the affected will be provided with modern houses, modern infrastructure (roads, electricity and water pipes), social services (school and health centre), and additional pasture land for cattle at the new settlements. The total area for compensation of land was settled at 1,700 acres and was bought by KenGen from Kedong Ranch Ltd. (Murage 2012). KenGen's title deed is supposed to be signed over to the affected Maasai, who had chosen this piece of land out of several alternatives. The resettlement planning was accompanied by about 30 meetings with elected community representatives and villages' councils of elders (GIBB Africa 2012, 2-5 to 2-7; KenGen 2012, Appendix 7-9).

Whether the resettlement exercise will finally be as successful as its planning cannot yet be told because the affected Maasai have not yet moved and re-established their livelihoods. However, the planning complies with crucial provisions of OP 4.12 such as the provision of resettlement alternatives (nine in total), prompt and effective compensation (annually up-updated compensation matrix), compensation for those who only have customary land claims and for community resources as well as restoration of public services $(1,700$ acres of land instead of only 84 acres of the official villages), preservation of social units by not splitting existing village communities, the facilitation of stakeholder participation in the planning and implementation of the resettlement, and even use of technologies that reduce emissions and thus the need for relocation (see paras. 6, 13, 15; Mwangi-Gachau 2011).

This is not the usual way how evictions have been carried out in Kenya. The Maasai of Olkaria usually had been displaced from their ancestral lands without adequate compensation, with many Maasai becoming illegal squatters as a result (Bw'Obuya 2002, 33). The safeguards thus potentially help guarding many substantial human rights such as the right to an adequate standard of living or the right to health.

A closer look at the de facto procedures, however, reveals weaknesses. Firstly, only two days were given between the first notice that the communities had to move and the first census (GIBB Africa 2012, 2). Two days are arguably not in line with OP 4.12 (13(a)) to 
provide the affected with 'timely and relevant information', which would allow them to deliberate and consult on their options properly.

Secondly, the area which was vacated for the plant comprises 4,200 acres and there exists no assessment whether the 1,700 acres will suffice to maintain the cattle of the pastoralist Maasai. Further, Kedong Ranch Ltd. has asked to fence the area, which would hinder the Maasai to switch to neighbouring grasslands if necessary (for example during droughts). Asking why they are compensated only 1,700 acres they were advised that they had no title deed to any of the land (KenGen 2012, 117). This arguably contravenes OP 4.12 (13(b)), according to which 'similar resources are provided to compensate for the loss of access to community resources...'

Thirdly, the process of agreeing to the vacation of the land was accompanied by allegations of an opposing group of affected Maasai. They accused other community members who had given a letter of agreement to KenGen of being compromised and the letter thus being illegal, and the subsequent election of new community representatives, supervised by a cabinet minister, was allegedly manipulated (Kimani 22.01.2011). There is no indication that these allegations have been investigated or that the legitimacy of the letter has been put in question by the government. Assuming that the allegations are based on evidence, this would contradict the requirement of OP 4.10 to obtain 'broad community support' in cases of relocation of indigenous people and to conduct 'meaningful and in good faith consultations' (OP 4.10, FN 4). These weaknesses of procedures finally resulted in the violent eviction of the cabinet minister from community meetings, public protests, and increased presence of security forces in the area (Kimani 2011).

All those allegations may indicate a breach of the right of indigenous people to their ancestral lands as well as of the FPIC principle by the Kenyan Government. Though Kenya did not support UNDRIP it could, as a party to the African Charter and member of the African Union (AU), arguably be expected to follow the advisory opinion of the ACHPR that UNDRIP is in conformity with 'similar provisions contained in many other instruments adopted by the AU ...' (ACHPR 2007, para. 35). Similarly, the World Bank arguably failed adequately guiding the government to consider indigenous people rights within the project guidelines and did not include OP 4.10 as officially project relevant safeguard despite the Maasai being recognised by the ACHPR as indigenous people.

The creditors, however, responded to the incidents. In 2011 a Joint AFD-KfW-EIB Social Risk Supervision Mission came to the conclusion that KenGen should establish a grievance mechanism as a 'forward looking communication strategy' (GIBB Africa 2012, Annex 2). This mechanism took the form of an operational-level grievance mechanism, which 
was mainly conceptualised to settle questions regarding details of the implementation of the resettlement. If disputes cannot be settled, the stakeholders can call for adjudication by an independent third party. Unfortunately, the costs for this next level are not covered by the project but stakeholders have to bear them themselves. Alternatively they can turn to the lenders for mediation. This contradicts Ruggie Guideline 31(d) and (h) to provide for an independent mechanism which takes power inequalities between stakeholders into account.

In spring 2013 tensions between the affected Maasai and KenGen increased again (Gitonga 07.05.2013). At the same time another ongoing land conflict became violent and led to the forced vacation of several villages from Maiella Ranch, including the village that should have been resettled under the World Bank's resettlement scheme due to air pollution. On 26 July reportedly around 200 hired and equipped youths with support of armed police officers burned or destroyed 60 houses, around 2000 people became homeless, and over 200 heads of livestock were killed in the fire (Murage 2013). The eviction was carried out on behalf of the landowners, the Ngati Farmers Cooperative Societey (NFCS), and backed by a court order. NFCS intended to sell the land to KenGen for further geothermal drillings, and the vacation was allegedly made a precondition for the land deal. The Maiella Maasai living on the NFCS farmland refused to move and instead issued a petition to the National Land Commission claiming the land themselves only one week before the forceful evictions took place (Koissaba 2013). In a press statement the World Bank denied any responsibility because the eviction was neither directly related to Olkaria IV nor to the Bank's KEEP programme (World Bank 2013).

It could, however, be argued that the affected became victims of national and international policies to expand geothermal explorations in Kenya and the African Rift more generally such as ARGeo. This provides economic opportunities for landowners, including those whose legal ownership might be challenged by claims of indigenous people.

Moreover, KenGen in 2011 stated in a paper on the Olkaria relocation, presented at a public conference, that the village on Maiella Ranch would not be covered by the resettlement scheme despite the fact that the relocation plans of GIBB Africa and KenGen of 2012 said the contrary. This might indicate that KenGen had different ideas about the relocation exercise than the lenders. It also indicates that KenGen seemingly acts differently as soon as no external safeguards are put in place. The case thus demonstrates that it cannot suffice for the CDM to rely on safeguards that are by chance applied by involved donors and lenders because not all CDM projects are accompanied by this type of funding.

The CDM registration process for Olkaria IV was, however, unspectacular. The PDD mentions the land dispute on Kedong Ranch, the claim of the Maasai to be considered in job 
offerings and to get appropriate compensation. KenGen's summarised response in the PDD is that relocations will be organised according to standards, that funds will be provided for community projects, and that Maasai applications for jobs will be considered in case of appropriate skills, but it does not include, for instance, an offer for appropriate job training, (CDM Executive Board 2012, 28f.). The PDD recognises that $99 \%$ of respondents have been aware of the project, which is not surprising considering its relevance for local livelihoods and media coverage. Unfortunately, the PDD does not include any documentation of the local stakeholder consultation process and whether also opponents with their complaints had been heard. The global stakeholder consultation was without response. As the DOE received, in its view, no major objections against the project, the registration was enacted on 17 June 2013 , around the same time that the quarrels started again.

The main human rights duty bearer is the State of Kenya, even more so as it owns a 70\% share of KenGen (GIBB Africa 2012, Appendix 2). However, also the World Bank and its board should incorporate rights-based principles such as FPIC in the applied social safeguards, and the Bank should give guidance to lending countries accordingly. The group of lenders, in particular the EIB, which is directly subject to the EU's human rights commitments introduced by the Lisbon Treaty, failed to design an operational-level grievance mechanism that builds upon the human rights-based Ruggie Guidelines.

\section{Conclusions: Options for Integrating Human Rights in Climate Policies}

Both case studies show that CDM projects potentially feed into pre-existing conflicts. In both cases this is related to conflicts over land ownership, which confirms the observation of the ICESCR treaty body in its General Comment No. 7 on forced evictions and the right to housing that conflicts over land are a major problem in case of development-based evictions. The cases indicate that responsibilities of host governments for human rights infringements in the context of CDM projects might range from direct and gross violations by state security forces as in Bajo Aguán to dubious behaviour of companies as in Olkaria and the omission or failure of a host state to protect from both. Additionally, the case of Olkaria on the one hand demonstrates that social safeguard policies, here applied due to World Bank involvement, can have a positive impact on the affected. On the other hand it shows, firstly, that the procedural rules and their implementation require more attention and precise guidance. Secondly, it demonstrates that the CDM cannot rely on social safeguards applied by chance due to donor involvement. The evictions in the neighbourhood of Olkaria IV indicate that the same company can behave differently if it feels no pressure to comply with social standards. From both cases it follows that the CDM needs a mandate of its own to apply social 
safeguard policies, firstly to provide the same guidance for all kinds and constellations of stakeholders, and secondly to be in the position to reject or withdraw project registrations if necessary. In case of Bajo Aguán this would at least have prevented the provision of international resources to an alleged perpetrator of grave human rights violations.

In our regard such guidelines should be human rights-based. Based on the elaborations on ETOs in sub-chapter 3, we argue that not just the host states but also international donors, financial institutions, credit buyers and private investors involved in the CDM or individual projects have human rights obligations. Based on interpretation of the ICESCR mainly, states can be deemed to have a responsibility not to undermine the enjoyment of human rights on foreign territory; to prevent third parties from abusing human rights by political and legal means; and to support the fulfilment of those rights through individual and international cooperation.

Nonetheless, human rights are so far not mentioned anywhere in the CDM's rules and procedures and ensuring projects' contribution to sustainable development and adequate stakeholder consultations is decentralised and left to each host country individually. Previous research has concluded that most countries only have very general sustainable development criteria, that the claims made by projects are usually not thoroughly assessed, and that stakeholder consultations are often rudimentary and badly documented.

It is therefore recommendable to develop mandatory human rights safeguards at the UNFCCC level. In the best case, these would help to avoid human rights violations by providing standards and guidance for realising human rights-compatible CDM projects. At a minimum, they would prevent the CDM from becoming involved in pre-existing situations that involve human rights violations, as in the Bajo Aguán project.

As a first step states who are parties to human rights treaties should comply with their duty to use their voting power in the UNFCCC to ensure that its mechanisms do not impact negatively on human rights. They thus should continuously lobby for a human rights-based understanding of sustainable development within the UNFCCC, which matches its meaning in respective declarations on sustainable development.

Following the Maastricht Principles the UNFCCC could and should require all projects to undergo a human rights impact assessment (HRIA) with clear procedural requirements for stakeholder consultations, making projects with negative impacts ineligible for registration. Similarly, the Ruggie Guidelines call on states to require human rights due diligence from companies in cases of a state-business nexus. Consequently, there should also be a 
procedure to de-register projects in cases where human rights violations become apparent only during implementation.

Applied procedural requirements should include access to redress, i.e. complaints mechanisms, internationally, nationally and at the operational-level. Operational-level grievance mechanisms should at least comply with the internationally accepted Ruggie Guidelines on business and human rights.

As many projects under the CDM and other UNFCCC mechanisms are related to the exploitation or preservation of natural resources, particular attention should be given to the rights of indigenous people and their related property rights. This should ideally include taking into account the provisions of UNDRIP and its interpretation of FPIC.

Such reform of CDM registration procedures would require a respective mandate for the DOE to assess those additional standards.

However, developing countries have so far strongly rejected all suggestions to internationally define standards for sustainability assessments and stakeholder consultations as infringements of their national sovereignty.

If no movement is possible at the UNFCCC level, individual buyer countries or groups of countries, such as the EU, could alternatively introduce their own additional requirements for CDM projects. Indeed, the EU is bound to the amendments of the Lisbon Treaty with their commitment to extraterritorial human rights obligations, at a minimum an obligation to respect. More concretely, the EU and EU countries have three possible points of intervention.

Firstly, the transfer of CERs to industrialised countries requires the issuance of a letter of approval to the project by an industrialised country. Cournil et al (2012) suggest that EU member states could decide to only issue approvals to CDM projects on the basis of a HRIA.

Secondly, several EU countries are themselves substantial buyers of CERs. They could therefore require the same safeguards from the projects they purchase CERs from as Cournil et al (2012) propose for the issuance of letters of approval.

Thirdly, the EU could decide to only allow credits from projects in the EU ETS that have undergone an HRIA. In addition, since each CER has a unique serial number which includes a project identifier, CERs from projects that are involved in human rights violations could also be individually banned from use in the EU ETS. 
The unique serial numbers also offer potential to use naming and shaming by publicly denouncing CERs from problematic projects as 'toxic' assets, in order to discourage potential buyers from acquiring those CERs.

Introduction of mandatory human rights safeguards would increase the CDM's transaction costs. A sense of the size of the additional cost that would be caused by introduction of human rights safeguards may be gained by analysis of the CDM Gold Standard, a voluntary label that includes social and environmental criteria as well as mandatory procedures for how to conduct local stakeholder consultations. An empirical study of Gold Standard projects found that the project developers generally deemed the requirements to be manageable with a reasonable amount of additional work (Sterk et al. 2009). The introduction of human rights safeguards can thus be expected to entail a significant but not insurmountable cost impact. From the viewpoint of human rights there is no excuse to make the most vulnerable groups bear the social costs of mitigation in order for industrialised countries to be able to exercise their emission rights (Schade 2012).

Finally, the human rights dimension of the restructuring of economies is not only an issue for the CDM but also for other mechanisms and initiatives to foment low-fossil economies. These should equally be reviewed for their human rights implications. 


\section{References}

ACHPR (2007) 'Advisory Opinion of the African Commission on Human and Peoples' Rights on the United Nations Declaration on the Rights of Indigenous Peoples', adopted by the African Commission on Human and Peoples' Rights at its 41st Ordinary Session held in May 2007 in Accra, Ghana, edited by African Union, Accra, Ghana,<http://www1.chr.up.ac.za/chr_old/indigenous/acwg/07-0808AdvisoryOpinionENG_1.pdf>, , accessed 28 June 2013

ACHPR-WG (2006) 'Indigenous Peoples in Africa. The Forgotten Peoples?', 30 October , <http://www1.chr.up.ac.za/images/files/documents/indigenous/african_commission_workin g_group/acwg_report_summary_english.pdf>, accessed 28 June $201 \overline{3}$

Bartels, Lorand (2014) 'A model human rights clause for the EU's international agreements', edited by Misereor and DIMR, Aachen / Berlin

Bw'Obuya, Nicholas M (2002) 'The socio-economic and environmental impact of geothermal energy on the poor in Kenya. The impact of a geothermal power plant on a poor rural community in Kenya', Nairobi, <http://www.e-

renewables.com/documents/Geothermal/Geothermal\%20on\%20Economics\%20in\%20Ke nya.pdf>, accessed 28 July 2013

CDM Executive Board (2012) 'Project Design Document (PDD). Olkaria IV Geothermal Project', UNFCCC,

<http://cdm.unfccc.int/Projects/Validation/DB/2DVWX16DKK0F3H2VMZQ3Z4AI7FV1BJ/vi ew.html>, accessed 30 July 2013

CDM Watch (2011a) 'Unsolicited Letter: Registration Request Aguan biogas recovery from Palm Oil Mill Effluent Project 3197, Honduras', 4 January,

$<$ http://carbonmarketwatch.org/cdm-project-application-3197-aguan-biogas-recovery-frompalm-oil-mill-effluent-pome-ponds-and-biogas-utilisation-exportadora-del-atlanticoaguanhonduras/>, accessed 30 July 2013

- (2011b) 'Open Letter to UK: UK Government must withdraw authorisation for Aguan and Lean CDM projects linked to assassinations and other human rights abuses in Honduras', 14 February, <http://carbonmarketwatch.org/open-letter-uk-government-must-withdrawauthorisation-for-aguan-and-lean-cdm-projects-linked-to-assassinations-and-otherhuman-rights-abuses-in-honduras/>, accessed 30 July 2013

— (2011c) 'Unsolicited Letter: Inadequacy of local stakeholder consultation of CDM project 3197, Bajo Aguan, Honduras', 24 June, <http://carbonmarketwatch.org/unsolicited-letterinadequacy-of-local-stakeholder-consultation-of-cdm-project-3197-bajo-aguan-honduras/> accessed 30 July 2013

CEMIRIDE (n.d.) 'The Case of Olkaria Maasai. Harmful Development Processes and the Culpability of the State', Centre for Minority Rights Development,

<http://www.chr.up.ac.za/chr_old/indigenous/documents/Kenya/Report/Olkaria_advc_rept. pdf>, accessed 30 July 2013

Cernea, Michael M (1997) 'The risks and reconstruction model for resettling displaced people', World Development, 25:10, 1569-1587

Cournil, Christel, Christine Colard-Fabregoule, Despina Sinou, Sandrine Maljean-Dubois, Chloé Vlassopoulos, Anne-Sophie Tabeau, Isabelle Verdier-Büschel and Adélie Pomade (2012) 'Human rights and climate change: EU policy options', European Parliament, Brussels

Craven, Matthew (2007) 'Extra-territorial application of the ICESCR', in Mashood Baderin and Robert McCorquodale (eds) The violence of dispossession: extra-territoriality and economic, social and cultural rights in action (Oxford, United Kingdom: Oxford University Press), 71-88

EurActiv (2011) 'Carbon credits tarnished by human rights "disgrace"', $<$ http://www.euractiv.com/climate-environment/carbon-credits-tarnished-human-r-news508068>, accessed 30 July 2013 
Exportadora del Atlántico (2011) 'Clean Development Mechanism Project Design Document, Aguan biogas recovery from Palm Oil Mill Effluent (POME) ponds and biogas utilisation Exportadora del Atlántico, Aguan/Honduras', Version 6, 25 January, $<$ http://cdm.unfccc.int/Projects/DB/TUEV-SUED1260202521.42/view>, accessed 30 July 2013

Exportadora del Atlántico and EDF Trading (2007) 'Clean Development Mechanism Project Design Document, Aguan biogas recovery from Palm Oil Mill Effluent (POME) ponds and biogas / biomass utilisation - Exportadora del Atlántico, Aguan/Honduras', Version 1, 18 December, <http://www.netinform.net/KE/Wegweiser/Guide2_3.aspx?ID=4204\&Ebene1_ID=26\&Ebe ne2_ID=1275\&mode $=0>$, accessed 30 July 2013

FIAN International (2013) 'Honduras - Bajo Aguan', <http://www.fian.org/en/what-wedo/case-work/honduras-bajo-aguan/>, accessed 30 July 2013

FIDH, APRODEV, CIFCA, Latin American regional branch of the International Union of Food, Agricultural Hotel Restaurant Catering Tobacco and Allied Workers' Associations, FIAN International and Vía Campesina International (2011) 'Honduras: Human Rights Violations in Bajo Aguán', Paris, FIDH <http://www.fidh.org/IMG/pdf/honduras573ang.pdf>, accessed 30 July 2013

Frank, Dana (2011) 'WikiLeaks Honduras: US linked to brutal businessman', The Nation, October 21, <http://www.thenation.com/article/164120/wikileaks-honduras-us-linkedbrutal-businessman\#>, accessed 30 July 2013

GIBB Africa (2012) 'Olkaria IV (Domes) Geothermal Project in Naivasha District. Resettlement Action Plan for Olkaria IV Power Station', JK000454, <http://www.kengen.co.ke/userfiles/OLKARIA\%20IV\%20RAP\%20FOR\%20DISCLOSURE _JULY\%20\%202012.pdf>, accessed 30 July 2013

Gitonga, Antony (2013) 'Maasai community demand written MoU from KenGen before relocation', Standard Digital News, 7 May , <https://www.standardmedia.co.ke/?articlelD=2000083139\&story_title=maasaicommunity-demand-written-mou-from-kengen-before-relocation>, accessed 30 December 2013

Heydenreich, Christine, Armin Paasch and Johanna Kusch (2014) ,Bericht 2014. Globales Wirtschaften und Menschenrechte: Deutschland auf dem Prüfstand', Misereor and German Watch, Aachen / Berlin

Huhne, Chris (2011) 'Request to withdraw UK authorisation of the Aguan biogas recovery project in Honduras', 4 April, <http://carbonmarketwatch.org/wpcontent/uploads/2011/02/UK_Gov_reponse_on_aguan_130411.pdf>, accessed 30 July 2013

IACHR Media Center (2011) 'Press Release: IACHR Brings its 143rd Regular Session to a Close, 4 November 2011', <http://www.oas.org/en/iachr/media_center/PReleases/2011/117.asp>, accessed 29 July 2013

ICJ (2011) 'Maastricht Principles on Extraterritorial Obligations of States in the Area of Economic, Social and Cultural Rights', published by FIAN International, Heidelberg

KenGen (2012) 'Environmental \& Social Impact Assessment Study Report for the Proposed Construction of Houses and Other Facilities for Resettlement of Olkaria IV Project Affected Persons at Olkaria Domes, Naivasha District', with assistance of Philip Barasa, Nairobi, <http://www.nema.go.ke/index.php?option=com_phocadownload\&view=category\&downlo ad=410:eia903esia-study-for-resettlement-of-olkaria-iv-paps-2nd-nov2012pdf\&id=110:eia900-909-reports>, accessed 30 December 2013

Kimani, Joyce (2011) 'Ntimama flees after Naivasha meeting erupts again', Daily Nation, January 22, <http://allafrica.com/stories/201101240121.html>, accessed 30 July 2013 
Knox, John (2009) 'Climate change and human rights', Virginia Journal of International Law, $50: 1,163-218$

Koissaba, Ben Ole (2013) 'A ticking time bomb', TWN - Third World Network,August, <http://www.twnside.org.sg/twnf/2013/3989.htm>, accessed 30 December 2013

Murage, George (2012) 'KenGen buys 1,700 acres for resettlement', The Star, 22 September, <http://allafrica.com/stories/201209230022.html>, accessed 30 July 2013 (2013) 'Anxiety as police evict 16 families from Naivasha Plot', The Star, 27 July , $<$ http://www.the-star.co.ke/news/article-129768/anxiety-police-evict-16-families-naivashaplot>, accessed 30 December 2013

Mwangi-Gachau, Elizabeth (2011) 'Resettlement of project affected persons. A case of Olkaria IV (Domes) geothermal project in Naivasha District, Kenya', KenGen (Nairobi), <http://www.gak.co.ke/nibs/web_resources/RESETTLEMENT\%200F\%20PROJECT\%20 AFFECTED\%20PERSONS\%20A\%20CASE\%20OF\%20OLKARIA\%20IV\%20(DOMES)\%20GEOTHERMAL\%20PRO JECT\%20IN\%20NAIVA.pdf >, accessed 15 March2013

OHCHR (2013) 'Private military and security companies in Honduras need robust and effective monitoring, says UN expert group, Tegucigalpa/Geneva', 25 February, <http://www.ohchr.org/EN/NewsEvents/Pages/DisplayNews.aspx?NewsID=13032\&Langl $\mathrm{D}=\mathrm{E}>$, accessed 29 July 2013

Olsen, Karen H (2007) 'The clean development mechanism's contribution to sustainable development: a review of the literature', Climatic Change, 84:1, 59-73

Republic of Kenya (2010) 'Kenya Electricity Expansion Project. Draft Indigenous Peoples Planning Framework (IPPF)', January 2010, $<$ http://www.kplc.co.ke/fileadmin/user_upload/Documents/072012/Media/Draft_IPP_Framework_Disclosure.pdf>, accessed 28 June 2013

Schade, Jeanette (2012) 'Les migrants des politiques climatiques. Nouveaux défis face aux déplacements générés par le changement climatique', Revue de Cultures et Conflits, 88:4, 85-110

Schneider, Lambert (2007) 'Is the CDM fulfilling its environmental and sustainable development objective? An evaluation of the CDM and options for improvement', ÖkoInstitut, Berlin, <http://www.oeko.de/oekodoc/622/2007-162-en.pdf>, accessed 30 July 2013

Schutter, Olivier de et al (2012) 'Commentary to the Maastricht Principles on extraterritorial obligations of states in the area of economic, social and cultural rights', February 29, <http://209.240.139.114/wp-content/uploads/2012/03/maastricht-principlescommentary.pdf>, accessed 2 July 2013

Sterk, Wolfgang (2012) 'Bericht 69. Sitzung Clean Development Mechanism Executive Board, 9-13 September 2012', Wuppertal Institut für Klima, Umwelt, Energie, Wuppertal, http://jiko-bmu.de/1168, accessed 30 July 2013

Sterk, Wolfgang, Frederic Rudolph, Christof Arens, Urda Eichhorst, Dagmar Kiyar, Hanna Wang-Helmreich and Magdalene Swiderski (2009) 'Further Development of the ProjectBased Mechanisms in a Post-2012 Regime', Wuppertal Institute for Climate, Environment, Energy, Wuppertal, <http://jiko-bmu.de/1168>, accessed 30 July 2013

Tamang, Parshuram (2005) 'An overview of the principle of free, prior and informed consent and indigenous peoples in international and domestic law and practices' (New York) $<$ http://www.agentschapnl.nl/sites/default/files/bijlagen/36\%20Workshop\%20on\%20Free, \%20Prior\%20and\%20Informed\%20Consent.pdf>, accessed 28 June 2013

TERI (2012) 'Assessing the Impact of the Clean Development Mechanism on Sustainable Development and Technology Transfer', TERI, New Delhi

TJRC (2013a) 'Report of the Truth, Justice and Reconciliation Commission', volume IIB,edited by TJRC. <http://nisisikenya.com/wpcontent/uploads/2013/06/TJRC_report_Volume_2B.pdf>, accessed 30 December 2013 
TJRC (2013b) 'Report of the Truth, Justice and Reconciliation Commission', volume IIA, edited by TJRC, Nairobi, <http://nisisikenya.com/wp-

content/uploads/2013/06/TJRC_report_Volume_2A1.pdf>, accessed 30 December 2013

Tsuma, Arthur (2012) 'Electricity company acquires land for thermal projects', The Star, December 24, <http://allafrica.com/stories/201209250066.html >, accessed 13 March 2013

TÜV Süd (2011) 'Validation Report, Exportadora del Atlántico, Validation of the CDM-Projekt: Aguan Biogas Recovery from Palm Oil Mill Effluent (POME) Ponds and Biogas Utilisation - Exportadora del Atlántico, Aguan/Honduras', Report No. 1095591, 31 January, <http://cdm.unfccc.int/Projects/DB/TUEV-SUED1260202521.42/view>, accessed 13 March 2013.

UNEP Risø (2014) ‘UNEP Risø CDM/JI Pipeline Analysis and Database’, 1 January 2014, <http://cdmpipeline.org/publications/CDMPipeline.xlsx>, accessed 17 January 2014

United Nations (2010) 'Report of the Secretary General's High Level Advisory Group on Climate Financing', United Nations, New York

Ward, Tara (2011) 'The right to free, prior, and informed consent: indigenous peoples' participation rights within international law', Northwestern Journal of International Human Rights, 10:2, 54-84

World Bank (2004) 'Legal Note on Free Prior and Informed Consultation', August 02

_- (2001) 'Operational Policy 4.12 - Involuntary Resettlement', revised February 2011

— (2005) 'Operational Policy 4.10 - Indigenous Peoples', revised April 2014.

_ (2013) 'World Bank Statement on Olkaria Maasai Evictions', Nairobi, 26 September, <http://www.worldbank.org/en/news/press-release/2013/09/26/world-bank-statement-onolkaria-maasai-evictions>, accessed 27 October 2013

Yamin, Farhana, and Joanna Depledge (2004) The international climate change regime, a guide to rules, institutions, and procedures (Cambridge et al.: Cambridge University Press)

Young, Laura A and Korir Sing'Oei (2011) Land, livelihoods and identities. Inter-community conflicts in East Africa (London: Minority Rights Group International) 